\title{
Donald H. Reigel
}

Pediatric Neurosurgery was founded by Bruce Hendrick and Don Reigel in 1985. Some questioned the need for a journal dedicated solely to pediatric neurosurgery. Since then, Pediatric Neurosurgery has become the official journal of the American Society of Pediatric Neurosurgeons (ASPN) and the publication voice of American pediatric neurosurgery. Throughout the 14 years of publication, Pediatric Neurosurgery has had one Managing Editor, Donald Reigel. Don saw the need for a high-quality pediatric neurosurgical journal, and with minimal support brought it into existence. Nearly single-handedly, he sustained the journal through some difficult times.

Don Reigel did the same thing for the ASPN 20 years ago. He saw the need, convinced practicing pediatric neurosurgeons that the time had come, called 17 pediatric neurosurgeons together in Pittsburgh, and established the ASPN. Don Reigel later served as the President of ASPN. He also served as Chairman of the Pediatric Section of the American Association of Neurological Surgeons and as Chairman of the American Board of Pediatric Neurological Surgery. I would argue that Don Reigel has had a greater influence on the development of organized pediatric neurosurgery in North America than any other person. Through all of this, Don never took his eyes off the prize, a better life for the child.

Don Reigel retired from the active practice of pediatric neurosurgery and as Managing Editor of Pediatric Neurosurgery in June of 1998, to dedicate his full attention to the Woodlands Project. Many of you are familiar with this project. Don and Gay Reigel have and will continue to assist young people with chronic disease reach their maximum potential. They have taught us much about children with central nervous system disease and how to care for them.

I attended one of Don's retirement dinners and was amazed by the outpouring of love and respect shown for this great man by his colleagues, community leaders, and families of the children.

Donald, we wish you Godspeed. Thank you from the Editorial Staff of Pediatric Neurosurgery.

David G. McLone, MD, $\mathrm{PhD}$

Editor-in-Chief

Chicago, Ill., USA

\begin{tabular}{ll}
\hline KARGER & ( 1998 S. Karger AG, Basel \\
Fax +4161306 1234 & \\
$\begin{array}{l}\text { E-Mail karger@karger.ch } \\
\text { www.karger.com }\end{array}$ & $\begin{array}{l}\text { Accessible online at: } \\
\text { http://BioMedNet.com/karger }\end{array}$
\end{tabular}

